\title{
Foreword
}

\section{John Walton - Inspiration and Founder of Muscular Dystrophy UK}

\author{
Robert Meadowcroft* \\ Muscular Dystrophy UK, London, UK
}

I am delighted to have this opportunity to mark Professor Lord Walton's outstanding personal contribution to Muscular Dystrophy UK or, as the charity was known when founded in 1959, the Muscular Dystrophy Group of Great Britain and Northern Ireland.

It is remarkable that John Walton has maintained such loyal and committed support for the charity over so many years. It is difficult if not impossible to think of anyone else who has made a similar, lifelong contribution in giving support and showing complete dedication to a single cause in this way.

In his autobiography, 'The Spice of Life', John recounts how he started work as a young doctor with Professor Fred Nattrass at Newcastle. Through their clinical practice, they developed a shared interest in understanding the underlying causes of muscular dystrophy and related neuromuscular conditions and, further, the need for research and greatly improved clinical care. They established the Muscular Dystrophy Group initially as an interest group within the unfortunately named Central Council for the Care of Cripples in the mid-1950s before the Group broke away from the Central Council in 1959 and was established as a charity in its own right.

The charity's founding members were John and Professor Nattrass together with a successful Birmingham businessman called Joe Patrick who had a son with Duchenne muscular dystrophy. John became the founding secretary, Professor Nattrass was the first Chairman and Joe Patrick became Vice Chairman. Led

*Correspondence to: Robert Meadowcroft, Muscular Dystrophy UK, 61A Great Suffolk Street, London SE1 0BU, UK. Tel.: +44 207 803 4800; E-mail: R.Meadowcroft@musculardystrophyuk.org. by John and his colleagues, the charity set out on its journey with limited resources, considerable energy and some useful business connections although the reputations of the young Walton and the more experienced Nattrass gave the charity great credibility within the research and healthcare community. When Richard Attenborough was moved to join them and give his full support to the charity in 1962, after meeting a group of boys with Duchenne muscular dystrophy, he brought an additional dimension with his celebrity connections from the glittering world of film and entertainment in which he was to become a huge figure in this country and indeed internationally.

John was the Chairman of the charity for 25 years, following Nattrass, after serving as Chairman of both the Research Committee and the Medical and Social Services Committee. As his career developed, his commitments and responsibilities grew to take more and more of his time and John had to take a less timeconsuming role with the charity. It is entirely fitting that his immeasurable contribution was recognised with his appointment as the charity's Honorary Life President.

In 1989, John's contribution to public life in fields such as medicine, science and education was recognised with his elevation to the House of Lords and he rapidly gained a well-earned reputation as an extremely effective and influential Parliamentarian. As a crossbencher (non-Party member), John commands the utmost respect and makes expert contributions to House of Lords debates on topics such as embryology, mitochondrial research and improving healthcare.

It is clear the John Walton Muscular Dystrophy Research Centre will continue to be at the forefront of expert clinical care and research not just in the UK but 
on the international stage too. John is a forward thinker who understood from the very start of his career the need to establish collaborative approaches and partnerships and the Centre very much reflects his approach. We are seeing huge strides in research and care led by Newcastle today, building on the vision and contribution of John and his colleagues over many years. Indeed, we have seen a first treatment licensed by the EMA to target nonsense mutations as the underlying cause of Duchenne muscular dystrophy affecting some $11-13 \%$ of boys with the condition. Given the number of potential treatments for muscle-wasting conditions now in clinical trials we can anticipate more treatments coming through to patients as a direct result of the contribution of John Walton to our field.

John is much loved and respected as the founder of the charity, a man whose long term vision, high standards and integrity laid the foundations for our work. We are deeply grateful for John's huge contribution both to the individuals and families affected by muscular dystrophy and related neuromuscular conditions and, of course, to our charity. It is right to say his contribution is unrivalled and it is difficult to imagine it can ever be equalled let alone surpassed. 